\title{
Global trends and competitiveness of the food industry
}

\section{Konkurentnost i globalni trendovi u prehrambenoj industriji}

\begin{abstract}
Food industry has a strategic role in the global economy and it greatly contributes to achieving the Sustainable Development Goals, but at the same time it causes significant ecological pollution and resource depletion. Maximizing the benefits and minimizing the costs of the food industry is therefore a challenging task. The subject of this paper are contemporary global trends and factors of competitiveness of the food industry. The purpose of the paper is to determine what contributes to the competitiveness of the food industry and to analyze recent global trends in the food industry in order to draw conclusions about the role and contribution of this industry to sustainable development and competitiveness. The analysis has shown that innovation in the production and processing of food and also diversification of the supply are key contributing factors. The main driver of innovation in the food industry are new consumer expectations and requirements. Consumers are increasingly concerned about their own ecological footprint, which increases the demand for those food products whose production has a minimal negative effect on the environment, and they often choose products of enterprises with socially responsible business practices.
\end{abstract}

Keywords: competitiveness, Sustainable Development Goals, global food industry

\section{JEL classification: F62}

\section{Sažetak}

Prehrambena industrija ima stratešku ulogu u globalnom gospodarstvu i uvelike doprinosi postizanju Ciljeva održivog razvoja, ali istodobno uzrokuje značajno ekološko zagađenje i iscrpljivanje resursa. Maksimiziranje koristi i smanjenje troškova od prehrambene industrije stoga je izazovan zadatak. Predmet ovog rada su suvremeni svjetski trendovi i čimbenici konkurentnosti prehrambene industrije. Svrha je rada analizirati što određuje razinu konkurentnosti i najnovije trendove u prehrambenoj industriji kako bi se izveli zaključci o ulozi i doprinosu prehrambene industrije održivom razvoju i konkurentnosti. Analiza je pokazala da su inovacije u proizvodnji i preradi hrane, kao i diverzifikacija ponude ključni za postizanje održivog razvoja i konkurentnosti. Glavni pokretač inovacija u prehrambenoj industriji su očekivanja i novi zahtjevi potrošača.Potrošači su sve više ekološki osviješteni i zabrinuti zbog vlastitog ekološkog otiska, što povećava potražnju za prehrambenim proizvodima čija proizvodnja ima minimalan negativan utjecaj na okoliš, pa često biraju proizvode poduzeća s društveno odgovornom poslovnom praksom.

Ključne riječi: konkurentnost, Ciljevi održivog razvoja, globalna prehrambena industrija JEL klasifikacija: F62

\section{Sanja Franc}

Assoc. prof.

Faculty of Economics and Business, University of Zagreb

E-mail:sfranc@efzg.hr

\section{Emanuel Kujevac, mag. oec}

Faculty of Economics and Business, University of Zagreb (student)

E-mail: ekujevac@net.efzg.hr

\section{Sanja Franc}

Izv. prof. dr.sc.

Ekonomski fakultet Sveučilišta u Zagrebu E-mail: sfranc@efzg.hr

Emanuel Kujevac, mag. oec. Ekonomski fakultet Sveučilišta u Zagrebu (student)

E-mail:ekujevac@net.efzg.hr 
Franc, S., Kujevac, E.

Global trends and competitiveness of the food industry

\section{Introduction}

The world market has become highly integrated and this is mostly due to the rapid growth of international exchange (Franc and Peulić, 2017). In today's open and integrated economy, the notion of competitiveness represents a focal point in economic policy design. Competitiveness is one of the key determinants of success in international trade and can be observed at the level of the national economy, industry and individual firm or a product. Porter (1990) points out that productivity is the only meaningful concept of competitiveness, that is, the value of output produced per unit of labor or capital.According to Porter,the determinant of national competitiveness is competitiveness of industries which lies in their ability to innovate.

The food industry has been facing rapid and constant changes caused by the last industrial revolution. Real-time data exchange between machines, gradual increase in autonomous production systems, and additive manufacturing techniques have significantly transformed the dynamics of many industries and competitiveness factors including food industry as well (Karacay, 2018).

The food industry is facing technological and economic changes reflected in the society, as well as in the production and processing of food, and in the entire value chain. Food producers are increasingly focusing on products that meet existing and new consumer demands for a healthy lifestyle. The innovation that have emerged in the food industry in recent years mainly relate to new scientific and technological approaches to food processing and the introduction of new types of food. In this regard, functional food has a very important role, as evidenced by the increased growth in demand resulting from increased health care costs, gradual increase in life expectancy and the desire of older generations for improved quality of life (Bigliardi and Galati, 2013).

The subject of this paper are contemporary global trends and factors of competitiveness of the food industry. The purpose of the paper is to determine what contributes to the competitiveness of food industry and to analyze recent trends in order to draw conclusions about the role and contribution of the food industry to sustainable development and competitiveness.

\section{Contemporary global trends in the food industry}

The growth of the global population as well as the growth of income in developing countries inevitably leads to the growth of demand for food. Consumers are becoming more environmentally and healthconscious, which is manifested in increased demand for healthier, lower-calorie food produced in a socially acceptable way. The COVID-19 pandemic has raised awareness of food safety and health, which has helped strengthen regulation in this field. The industry also faces challenges of sustainable development as it contributes significantly to environmental degradation, resource depletion and climate change.

The Ministry of Economy of the Republic of Croatia (2014) emphasizes the most important trends in the global food industry as: increasing production efficiency, demand for diversified products, food safety, greater importance of developing markets, business sustainability, company consolidation and value chain structuring. There is a trend of growth in food production due to global population growth. The growing trend of business takeovers and mergers, driven by historically low interest rates, has not bypassed even the world's largest food producers which also began to consolidate. New products and diversification are driven by new technological discoveries, and industry regulation is more focused on consumers and the environment.

In emerging markets, supply chain management is influenced by growing and changing consumption, while in developed markets the focus is on reducing costs and improving end-service. Here, there is also a trend of mergers, takeovers and joint ventures that enable enterprises to capture new markets, strengthen their market position, reduce costs and maximize productivity and business efficiency (Ministry of Economy of the Republic of Croatia, 2014).

The food industry accounts for the largest share of the European Union's manufacturing sector, and in 2018 it had a turnover of 1.205 trillion euros, employed 4.73 million people and generated 254.68 billion euros of new value added. It is also 
the sector with the highest capital expenditures in the European Union (EU), which in 2018 amounted to 45.56 billion euros (Eurostat, 2021). In Croatia, the Food and Beverage Production sector accounted for $2.9 \%$ of gross domestic product (GDP) and 22.5 $\%$ of the manufacturing industry in 2017 with 3.6 $\%$ share in total employment in 2019 (Palić, 2020).

Food and beverage production is especially important for the EU because it is the largest production activity in terms of number of employees and value added. The food industry in Europe is fragmented and dominated by small and medium-sized enterprises, which has an impact on the innovation capacity and investment in research and development, as larger enterprises have a higher investment capacity. EU food products are growing in the markets of India, China and Russia, while the share in the US and Japan is declining. Under the influence of globalization, higher valueadded products based on scientific research are rapidly developing (Ministry of Economy of the Republic of Croatia, 2014).

According to the European Commission (2016), trends affecting the dynamics of the food industry in the EU include: rising European and global income, demographic changes, changes in consumer preferences, changes in the supply chain and innovation. The above trends are described in more detail below.

The growth of European and global income represents an opportunity for the food industry because income growth implies greater demand for high-quality food products. Likewise, rising incomes in developing countries mean higher demand for cheaper food. Population growth is also a determinant of increasing demand for food products. An increase in the share of people over the age of 65 affects the change in the structure of demand. Older people require stronger-tasting foods and suitable structures. Poorer health in the elderly creates a demand for a personalized diet and nutritionally enriched food products, i.e. functional foods. The urbanization trend is also affecting the food industry. The role of supermarkets for food distribution is increasing, and there is a decrease in the number of employees in agriculture, while the number of employees in processing, transportation, wholesale and retail is increasing. Consumer preferences are influenced by various determinants, such as biological, economic, physical, social, psychological, and attitudes and beliefs. The most important factor when buying food is the price, and for people with higher incomes factors such as quality, safety, impact on health, etc. have a great influence as well. Current trend of increasing demand for the so-called "free from" food, such as gluten free and lactose free products, and organic foods. Customer concern for food safety has strengthened the demand for local products in order to increase confidence in such products and there has been an increase in interest in current food cultivation and processing practices due to the possibility of disease occurrence and transmission. Consumers are also increasingly concerned about the impact of the food industry on the environment and animal welfare, which encourages many food producers to implement the principles of sustainable business. Furthermore, the demand for organic food is growing and alternative channels for food distribution are being developed, and there are fewer EU buyers who consider genetically modified food safe. In the supply chain, there are trends of consolidation of retail chains, expansion of discount distributors and the creation of purchasing cooperatives in order to lower the purchase prices of products and increase the bargaining power of distributors. There is also a trend of vertical integration with producers to ensure stable supply of product stocks and control over the production process and procurement of primary raw materials, and the share of private labels in the food market or product reintroduction is growing. Finally, innovations in the food industry include new products and packaging, new formulations for food preservation, additives and flavors, implementation of new logistics processes, and new marketing methods. The main driver of innovation in the food industry are customer expectations and requirements. Investments in research and development have increased at a similar pace as in other sectors, with the most significant contributors being the leading food and beverage producers.

The food industry is influenced by Industry 4.0 trends. Akyazi et al. (2020) pointed out that the integration of technologies provided by Industry 4.0 will lead to a faster industrial transformation
Franc, S., Kujevac, E.

Global trends and competitiveness of the food industry 
Franc, S., Kujevac, E.

Global trends and competitiveness of the food industry in the food industry by facilitating the production of better quality food products in a shorter time and at a lower cost. In recent years new scientific and technological approaches to food processing are being developed and new types of food are introduced to the market. In this regard, functional food plays a very important role (Bigliardi and Galati, 2013). Functional foods are food products made from ingredients that provide certain health benefits in addition to those derived from essential nutrients and can prevent certain health problems and generally improve quality of life (Griffiths et al. 2009). The global functional food market was worth $\$ 258.8$ billion in 2019 and is estimated to be worth $\$ 529.66$ billion by 2028 (Fortune Business Insights Ltd., 2020). Demand for functional foods has also been driven by the COVID-19 pandemic which, among other things, has encouraged consumers to follow healthier diets to protect the immune system (Rodríguez-Pérez et al., 2020).

In addition to functional foods, the market for plant-based food is growing, replacing products of animal origin such as meat, milk, cheeses, fats and other.Aschemann-Witzel et al. (2020) point out that increased global demand for protein, insufficient protein intake of certain groups of the population, and the issue of health and sustainability have significantly contributed to the development of plant products based on plant proteins. The largest source of protein is animal-based protein, and it is assumed that this production is responsible for 15 $\%$ of $\mathrm{CO}_{2}$ emissions on the planet (Stoll-Kleemann and Schmidt, 2017).According to a global consumer survey conducted by Euromonitor International, 40 $\%$ of respondents said they strive to reduce animal protein intake, while $10 \%$ of respondents said they completely avoid red meat (Aschemann-Witzel et al., 2020). This certainly affects the way food is produced and the diversification of supply.

In addition to the already mentioned impact of the COVID-19 pandemic on the demand for healthier food products, the pandemic has raised the issue of product safety among producers, distributors and customers (Aday and Aday, 2020). The Internet of Things technology, which is one of the key components of Industry 4.0, can also make significant progress in food safety, as it enables identification and monitoring of food products from cultivation to the beginning of the production process (Zhao et al., 2015). Tan et al. (2017) highlighted supply chain integration as an important trend in ensuring food integrity and safety in the global supply chain. Supply chain integration is a strategic collaboration of intra-organizational and extra-organizational processes and enterprises that carefully link their activities with external partners (Frohlich and Westbrook, 2001). Integrated supply chains in the food industry are becoming increasingly common form of business to preserve products as well as to increase productivity due to low margins in the food industry. With better integrated supply chains, food products can be managed more efficiently. For example, fewer surplus food stocks along with a better integrated supply chain help reduce the cost of supplies and unusable products (Kittipanyangam and Tan, 2020).

The pandemic has also shaken the food industry along the entire supply chain causing a decrease in production, processing, transportation and logistics, and strong changes in demand. Despite the challenges, the supply chains have shown great resilience and the supply has returned to normal after the initial downturn. The pandemic has demonstrated the importance of an open and predictable international trade environment for efficient food trade (OECD, 2020). The impact of the pandemic is also visible in the strong rise of prices of all agricultural goods in the commodity markets, which has also caused the rise in food prices in stores (European Commission, 2021).

\section{Factors of competitiveness in the food industry}

Porter (1990) considered that the main determinant of national competitiveness is the competitiveness of industries. Industries are competitive if enterprises that make up the industry are innovative, because only by constant innovation can they create long-term and sustainable competitive advantages and thus be successful in the international market. Countries must encourage the innovation and productivity of industries in order to be internationally competitive. Industrial innovation, and therefore competitiveness, arises from four main factors: factors of production, demand conditions, related and supporting 
industries, and enterprise strategy, structure, and rivalry. According to Porter these four attributes constitute factors of industry competitiveness.

The European Commission (2014) concluded that industry level competitiveness and the favorable competitive position of the manufacturing industry are mostly influenced by a highly educated workforce, a high share of exports and the production of complex and high quality products. The competitiveness of enterprises is also determined by public administration, innovation and energy prices. Efficient public administration supports the creation of fast-growing enterprises and employment growth because it promotes higher revenues and facilitates easier market entry. The quality of the management system, an independent judiciary and the absence of corruption are particularly important for the efficiency of public administration. Innovation has proven to be an important factor in employment in manufacturing enterprises. In periods of economic expansion, innovators create more jobs than noninnovators due to the effect of higher sales of new products and during economic recession more jobs are preserved in innovator enterprises. Because of these factors, policies that support investment in innovation and research and development are key to increasing industrial competitiveness and maintaining employment. Another important factor of industry competitiveness is energy prices, which is especially pronounced in energy-intensive industries such as food industry. A significant role here is played by the dependence of EU countries on imports of energy sources such as oil and gas, which makes them more expensive than in many other economies. However, the energy needs of industries are declining due to technological advances and the expansion of renewable electricity use, but these factors have failed to fully reverse the effects of rising prices. Energy prices also vary significantly among countries, influenced by different energy tax rates and types of energy sources, so industries in countries with a significant share of renewable electricity production are exposed to lower costs (European Commission, 2014).

The International Trade Center (2007) has developed a methodology for analyzing industry level competitiveness. Trade Performance Index calculates the level of competitiveness and diversification of a particular export sector using comparisons with other countries and thus provides insight into the general profile and ranking of key export sectors, including static and dynamic indicators. Porter (1990) used the presence of significant and continuous exports of industry to a wide range of other countries and the presence of significant outgoing foreign direct investment based on knowledge and skills created in the home country as indicators of the export competitiveness of an industry. Siggel (2006) takes productivity and exports as the most commonly used variables for analyzing international industry competitiveness.

Bigliardi et al. (2020) investigated innovation models applied in the food industry. They concluded that linear innovation models are still the most prevalent globally. In European countries, especially in Italy, where the food industry ranks second in the manufacturing sector, funding for research and development is expected to increase. In fact, in a dynamic market like the one in the food sector, where more attention is paid to products and sustainability, a good innovative strategy is an element of successful competition.

Firlej et al. (2017) analyzed the competitiveness of the Polish food industry. They looked at indicators such as export orientation, import-export coverage, import penetration, and the revealed comparative advantages. The results indicated a high growth in the competitiveness of the Polish food industry. It should also be emphasized that the food industry is one of the largest beneficiaries of Poland's accession to the EU.

Szwacka-Mokrzycka (2010) points out that a high level of competitiveness ensures the maintenance and expansion of market share and balanced longterm development. Author lists five fundamental factors of food industry competitiveness: low production and distribution costs, high level of integration of production and capital, high product quality, constant technology development and efficient organizational system and enterprise management (Szwacka-Mokrzycka, 2010).

Hartmann and Schiefer (2008) explained the variations between the performance of German food enterprises. The authors defined eight variables that determine the competitiveness of
Franc, S., Kujevac, E.

Global trends and competitiveness of the food industry 
Franc, S., Kujevac, E.

Global trends and competitiveness of the food industry an enterprise: technology and factors related to production, market research, product innovation, quality of relationships, linkage to distributors and customers. bargaining power, involvement in foreign markets and employee qualifications. It was also found that the superior performance of the enterprise is mostly influenced by the reputation, the size of investments, relationships with suppliers and the competencies of the management. On the other hand, variables that less significantly affect business performance are the competencies of non-managerial staff and firm size (Hartmann and Schiefer, 2008).

\section{The role of the food industry in achieving the global sustainable development goals}

The notion of competitiveness is always associated with the issue of economic growth and increased well-being of the population. However, economic growth also entails certain risks, such as harmful effects on the environment and excessive extraction of natural resources. Economic growth can leave long-term harmful social and environmental consequences. In 1987, the World Commission on Environment and Development published a report entitled "Our Common Future" in which it presented the concept of sustainable development According to the commission's report, sustainable development is a form of development that meets the needs of today's generations without compromising the needs of future generations (WCED, 1987).

The World Conference on Sustainable Development, held in 2002, broadened the basic definition by establishing three pillars of sustainable development, namely the environment, the economy and the society. In this way, it expanded the framework of sustainable development, which previously applied only to the economy (Kates et al., 2012).

The United Nations Millennium Summit was held in 2000 and adopted the Millennium Declaration, which set out the values, principles and goals of the UN for the 21st century in the form of eight specific goals that needed to be achieved by 2015 . The latest progress made in the field of sustainable development is the United Nations report created at the Rio + 20 summit in 2012, which proposed the Sustainable Development Goals (SDGs) that have replaced the Millennium Declaration, which was valid until 2016 (Sachs, 2012).

The SDGs are a global strategy to improve health and education, reduce inequality and strengthen economic growth. These are 17 core goals and 169 sub-goals that are part of a global strategy to promote sustainable development (UN, 2021).

Sachs et al. (2019) presented 6 transformations of the SDGs which enable their successful achievement: 1) education, gender and inequality, 2) demography, health, and well-being, 3) decarbonization of energy and sustainable industry, 4) sustainable food, sustainable land and sustainable water, 5) sustainable communities and cities and 6) digital revolution. The food industry is key to achieving sustainable land, food and water. The interventions needed to achieve this goal are: efficient and resilient agricultural systems that support a healthy diet and livelihood of farmers, protection of terrestrial and aquatic biodiversity, promotion of healthy food and food regulation, trade and supply chain which support sustainable development, and integrated use of land and water resources. In order to meet SDGs, it is necessary that the transformations take place in an integrated manner (Sachs et al., 2019).

It can be said that the food industry faces significant challenges regarding sustainable development. Simultaneously, it contributes to the SDGs but also suffers from the consequences of ecological footprint, especially global warming and deforestation. Likewise, food industry is closely associated with farming communities by providing them with income and livelihoods, but is sometimes involved in land seizing that undermines the rights and well-being of the same communities. It feeds a growing population but also contributes to the epidemic of obesity and metabolic diseases, while malnutrition has worsened in recent years. In short, the food sector is at the heart of economic, social and environmental goals and requires the highest standards to meet global sustainable development goals (CCSI and SDNSN, 2019).

Food production accounts for 13.7 billion tons, or $26 \%$ of carbon dioxide emissions, and as much as $78 \%$ of eutrophication of salt and fresh water 
(Ritchie and Roser, 2021). Of the 102 million square kilometers of arable land, as much as half is covered by agricultural land, while the rest falls on forests, urban areas, fresh water and other vegetation. Agricultural production is responsible for $70 \%$ of global fresh water consumption, while industry and households account for $30 \%$. Of the total mass of mammals on earth, excluding the human population, as much as $94 \%$ falls on livestock, and only $6 \%$ refers to wild animals (Ritchie and Roser, 2021).

The United Nations Sustainable Development Solutions Network (SDNSN) and the Columbia Center for Sustainable Investment (CCSI) have developed a conceptual framework for defining corporate practices in the food industry in line with the SDGs. The purpose is to define measures, tools and rules for reporting the Sustainable Development Goals and to single out enterprises that contribute more than others. The framework for responsible corporate practices takes into account the alignment of business practices with SDGs and consists of four dimensions (CCSI and SDNSN, 2019):

1. Sustainable products - the impact of products and services on the sustainability and well-being of people.

2. Sustainable operations - refers to the environmental and social impact of business operations, including the use of resources.

3. Sustainable value chain - refers to the relationship of enterprises with other entities throughout the value chain, such as suppliers, customers and parallel industries, and the role of enterprises in promoting and supporting sustainable practices in the value chain.

4. Socially responsible behavior - refers to the way the enterprise is managed, i.e. the role of the enterprise in encouraging the internalization of externalities and the enterprise policies for achieving the SDGs.

Furthermore, a study conducted by CCSI and SDNSN (2019) together with partner organizations analyzed the reporting practices and standards of ten leading enterprises in the food industry. The study concluded that all analyzed enterprises have accepted sustainable development as a fundamental concept of their own business and their own co-responsibility in the supply chain. However, despite the good intentions shown, the reporting systems proved to be incomplete and enterprises more often emphasized their strengths than weaknesses in their reports. Enterprises do not publish detailed information on their supply chain, i.e. they do not provide information on the origin of raw materials and products. Therefore, it is difficult to determine the real environmental and social impact of the supply chain. Information on the composition and impact of food products on health are not detailed enough. Likewise, enterprises do not provide enough evidence on important aspects of corporate social responsibility. Different criteria, indicators and time frames are used for reporting the achievement of SDGs, and therefore a comprehensive reporting framework is needed. They propose four recommendations for transparent reporting and implementation of corporate practices to achieve the Sustainable Development Goals (CCSI and SDNSN, 2019):

1. The food industry should take into account all dimensions of responsible corporate practices, namely sustainable products that contribute to human health and well-being, sustainable business operations, sustainable supply chains and socially responsible behavior.

2. Introduction of comparable, harmonized and reliable monitoring and reporting systems based on four dimensions of responsible corporate practices.

3. Promoting a sustainable and healthy diet and life, informing consumers in detail about the nutritional composition of food products and generally improving quality.

4. Monitoring the supply chain of each group of food products, from suppliers to final consumers to ensure an economically, environmentally and socially sustainable supply chain and encourage innovation.

Maloni and Brown (2006) point out that the lack of a socially responsible supply chain can have a negative impact on an enterprise's profitability and market share due to the negative image that this deficiency creates in consumers. Therefore, enterprises need to seriously consider the benefits
Franc, S., Kujevac, E.

Global trends and competitiveness of the food industry 
Franc, S., Kujevac, E.

Global trends and competitiveness of the food industry of integrating socially responsible behavior practices into their supply chains. The issue of socially responsible behavior within the supply chain is becoming increasingly important, not only because of animal and plant raw materials, but also because of the labor-intensive nature of the supply chain. The authors have developed a framework for applying socially responsible behavior practices to the food industry supply chain consisting of eight dimensions: 1) animal welfare, 2) environment, 3) community, 4) biotechnology, 5) fair exchange, 6) health and safety, 7) labor and human rights and 8) supply (Maloni and Brown, 2006).

\section{Conclusion}

Food industry competitiveness rests upon many factors including export orientation, innovation, productivity and others. The most important trends prevailing in the global food industry relate to changes in consumer habits and structure. There is a significant trend of increasing demand for healthier food, which is the result of increased consumer awareness of the impact of food products on health and the growing share of the elderly population. Food industry has a strategic role in the global economy and it greatly contribute to achieving the SDGs, but at the same time, it causes significant ecological pollution and resource depletion. Maximizing the benefits and minimizing the costs of the food industry is therefore a challenging task. Part of the solution are innovation in the production and packaging of foods but also in diversification of the supply. The main driver of innovation in the food industry are new consumer expectations and requirements. Consumers are increasingly concerned about their own ecological footprint, which increases the demand for those food products whose production has a minimal negative effect on the environment, and they often choose products of enterprises with socially responsible business practices. Investments in research and development have increased at a similar pace as in other industrial sectors, with the most significant contributors being the leading food and beverage producers. Integrating socially responsible behavior practices into the performance of food producers can therefore significantly contribute to satisfying new consumer requirements and to achieving the global Sustainable Development Goals.

\section{References}

Aday, S., \& Aday, M. S. (2020). Impact of COVID-19 on the food supply chain. Food Quality and Safety, 4(4), 167-180. https://doi.org/10.1093/fqsafe/fyaa024

Akyazi, T., Goti, A., Oyarbide, A., Alberdi, E., \& Bayon, F. (2020). A Guide for the Food Industry to Meet the Future Skills Requirements Emerging with Industry 4.0. Foods, 9(4), 492. https://doi.org/10.3390/foods9040492

Aschemann-Witzel, J., Futtrup Gantriis, R., Fraga, P., \& Perez-Cueto, F. (2020). Plant-based food and protein trend from a business perspective: markets, consumers, and the challenges and opportunities in the future. Critical Reviews in Food Science and Nutrition, 61(18), 3119-3128. https://doi.org/10.1080/10408398.2020.1793730

Bigliardi, B., \& Galati, F. (2013). Innovation trends in the food industry: The case of functional foods. Trends in Food Science \& Technology, 31(2), 118-129. https://doi.org/10.1016/.j.tifs.2013.03.006

Bigliardi, B., Ferraro, G., Filippelli, S., \& Galati, F. (2020). Innovation Models in Food Industry: A Review of The Literature. Journal of Technology Management \& Innovation, 15(3), 97-108. http://dx.doi.org/10.4067/S0718-27242020000300097

CCSI \& SDNSN (2019). Sustainable Business Practices in the Food Sector: Developing a corporate action framework for SDG alignment. New York: Columbia University. 
European Commission (2014). Factors influencing industrial competitiveness in the EU. Bruxelles: European Commission.

European Commission (2016). The competitive position of the European food and drink industry. Bruxelless: European Comission.

Eurostat (2021). Database. Available at: https://ec.europa.eu/eurostat/web/structural-businessstatistics/ data/database?p_p_id=NavTreeportletprod_WAR_NavTreeportletprod_INSTANCE_Wg8pz4NjomG2\&p_p_ lifecycle $=0 \& p_{-} p_{-}$state $=$normal\&__p_mode $=\overline{\text { view }}(\overline{5} .8 .2021)$.

Firlej, K., Kowalska, A., \& Piwowar,A. (2017). Competitiveness and innovation of the Polish food industry. Agric. Econ. - Czech, 63, 502-509. https://doi.org/10.17221/111/2016-AGRICECON

Fortune Business Insights Ltd. (2020). Market research report. Available at: fortunebusinessinsights.com: https://www.fortunebusinessinsights.com/functional-foods-market-102269\#tableofcontent (5.8.2021).

Franc, S., \& Peulić, V. (2017). Examining Slovenian trade flow sustainability: empirical evidence from the period of the EU membership. Notitia - journal for sustainable development, 3(3), 25-34.

Frohlich,M.K., \& Westbrook,R.(2001).Arcs of integration: an international study of supply chain strategies. Journal of Operations Management, 19(2), 185-200. https://doi.org/10.1016/S0272-6963(00)00055-3

Hartmann, M., \& Schiefer,J. (2008). Determinants of Competitive Advantage for German Food Processors. Agribusiness, 24(3), 306-319. https://doi.org/10.1002/agr.20168

Karacay, G. (2018). Industry 4.0: Managing The Digital Transformation. New York: Springer International Publishing.

Kittipanya-ngam, P., \& Tan, K. (2020). A framework for food supply chain digitalization: lessons from Thailand. Production Planning \& Control The Management of Operations, 31(2-3), 158 - 172. https://doi.org/10.1080/09537287.2019.1631462

Maloni, M. J., \& Brown, M. E. (2006). Corporate Social Responsibility in the Supply Chain: An Application in the Food Industry. Journal of Business Ethics, 68, 35 - 52. https://doi.org/10.1007/s10551-006-9038-0

Ministarstvo gospodarstva Republike Hrvatske (2014). Industrijska strategija Republike Hrvatske 2014.2020. (cro.) Zagreb: Ministarstvo gospodarstva Republike Hrvatske.

OECD (2020). Food Supply Chains and COVID-19: Impacts and Policy Lessons. Paris: OECD.

Palić, P. (2020). Sektorske analize (cro.).Zagreb: Ekonomski institut Zagreb.

Porter, M. E. (1990). The Competitive Advantage of Nations. Harvard Business Review, 68(2), 74-91.

Ritchie, H., \& Roser, M. (2021). Environmental impacts of food production. Available at: https:// ourworldindata.org/environmental-impacts-of-food\#citatio (16.8. 2021).

Sachs, J. (2012). From Millennium Development Goals to Sustainable Development Goals. Lancet, 379(9832), 2206 - 2211. https://doi.org/10.1016/50140-6736(12)60685-0

Sachs, J., Schmidt-Traub, G., Mazzucato, M., Messner, D., Nakicenovic, N., \& Rockström, J. (2019). Six Transformations to achieve the Sustainable Development Goals. Nature Sustainability, 2, $805-814$. https://doi.org/10.1038/s41893-019-0352-9

Stoll-Kleemann, S., \& Schmidt, U. (2017). Reducing meat consumption in developed and transition countries to counter climate change and biodiversity loss: A review of influence factors. Regional Enviromental Change,17, 1261 - 1277. https://doi.org/10.1007/s10113-016-1057-5

Szwacka-Mokrzycka, J. (2010). Sources of Competitive Advantage in Food Industry. Social Responsibility, Professional Ethics, and Management Proceedings of the 11th International Conference, 823 - 844. Ankara: Mic.

Tan, K., Ali, M., Makhbul,Z., \& Ismail,A. (2017). The impact of external integration on halal food integrity. 
Franc, S., Kujevac, E.

Global trends and competitiveness of the food industry
Supply Chain Management: An International Journal, 22(2). https://doi.org/10.1108/SCM-05-2016-0171

UN (2021). Database.Available at: https://comtrade.un.org/data/ (28.8.2021).

UN (2017). Sustainable development goals. Available at: https://sdgs.un.org/2030agenda (28.8. 2021).

World Commission On Environment and Development (1987). Our Common Future. New York: Oxford University Press.

Zhao, X., Fan, H., Zhu, H., Fu, Z., \& Fu, H. (2015). The Design of the Internet of Things Solution for Food Supply Chain. 5th International Conference on Education, Management, Information and Medicine, 314 - 318. Changzhou: Atlantis Press. 